\title{
VIA CRUCIS de Clarice Lispector
}

\section{VIA CRUCIS by Clarice Lispector}

Rosina Bezerra de Mello Santos Rocha*

Teresinha Vania Zimbrão da SILVA**

\section{Resumo}

Neste artigo, trabalharemos com duas áreas de conhecimento que, anteriormente, estavam muito distanciadas no ambiente acadêmico, mas que, nos últimos anos, têm se aproximado: Literatura e Teologia. Nossa proposta é estabelecer um diálogo interdisciplinar e produtivo: analisaremos o conto da escritora brasileira Clarice Lispector (1920-1977), Via crucis, que integra o seu livro, $A$ via crucis do corpo, publicado em 1974, como reescritura do texto bíblico, cujo tema o próprio título do conto anuncia, ou seja, Via crucis. Explicitaremos a correlação entre os símbolos judaico-cristãos, expressos na narrativa original do nascimento e morte de Jesus Cristo, tal como descrita nas páginas da Bíblia, e a linguagem paródica usada pela ficcionista para narrar a sua versão da estória. Um dos nossos objetivos é chamar a atenção dos pesquisadores das áreas de Literatura e Teologia para a crescente importância e produtividade dos estudos interdisciplinares que colocam em diálogo essas duas áreas de conhecimento.

**Professora Dra. da Graduação e PósGraduação (Mestrado e Doutorado em Estudos Literários) da Faculdade de Letras da Universidade

Federal de Juiz de Fora. E-mail: teresinha. zimbrao@gmail.com

\section{Abstract}

In this article we will work with two areas 
of knowledge that were previously very distant in the academic environment and in recent years have been approached: Literature and Theology. Our proposal is to establish an interdisciplinary and productive dialogue: we will analyze the short story of Brazilian writer Clarice Lispector (1920-1977), Via crucis, which is part of her book, $A$ via crucis do corpo, published in 1974, as a rewriting of the biblical text, whose theme the very title of the short story announces, namely, Via crucis. We will explain the correlation between the Judeo-Christian symbols expressed in the original narrative of the birth and death of Jesus Christ, as described in the pages of the Bible, and the parody language used by the fictionist to narrate her version of the story. One of our goals is to draw the attention of researchers in the areas of Literature and Theology to the growing importance and productivity of interdisciplinary studies that bring into dialogue these two areas of knowledge.

Keywords: Clarice Lispector; Via Crucis; Parody.

\section{Introdução}

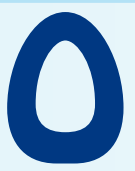

livro de contos A Via Crucis do Corpo, de Clarice Lispector, publicado em 19741, é o primeiro livro da autora escrito "por encomenda", "às pressas", "por dinheiro". Na época de sua publicação, o livro foi alvejado negativamente, ainda que a qualidade literária tivesse sido mantida, conforme assinalam os críticos Nunes (1989), Gotlib (1995) e Reguera (2006). No seu prefácio/explicação, a própria autora, antecipando a má recepção do livro, afirma: "Uma pessoa leu meus contos e disse que aquilo não era literatura, era lixo" (LISPECTOR, 1974, p. 10).

A explicação para a rejeição da crítica, segundo Nunes, Gotlib e Reguera, seria a temática adotada nos contos do livro: a sexualidade. Essa fora uma exigência do editor Paulo Pacheco. Sua intenção era que Clarice Lispector publicasse um livro erótico, muito em moda na época. Tanto Nunes quanto Reguera comentam que, para abordar o assunto solicitado, Clarice Lispector trabalhou a linguagem de tal modo que criou o que eles chamaram de encenação. Tal perspectiva considerava dois

1. A edição em estudo é a original: a 1ª edição, publicada em 1974 pela Artenova. 
aspectos: a simulação ("parecer" e "não-ser") e a dissimulação ("não-parecer" e "ser"), conforme esclarece Reguera (2006, p. 21). O recurso da encenação foi a forma dissimulada encontrada pela ficcionista para atender às exigências do mercado e do editor (escrever por encomenda e sobre sexualidade) e, ainda assim, exercer o espírito crítico e problematizador (REGUERA, 2006, p. 22-23).

Destaca-se que, de um lado, se a narradora encena algum sofrimento ao escrever sobre o tema exigido pelo editor, tal como registrado na epígrafe bíblica tirada às Lamentações de Jeremias: "Por essas cousas eu ando chorando. Os meus olhos destilam águas" (LISPECTOR, 1974, p. 8), ou ainda na explicação/prefácio: "vão me jogar pedras" (LISPECTOR, 1974, p. 10), em alusão à pecadora bíblica, de outro, há uma satisfação dissimulada, sugerida tanto na epígrafe bíblica apropriada por Clarice aos Salmos, "A minha alma está quebrantada pelo teu desejo" (LISPECTOR, 1974 , p. 8, SI 119, 2), quanto pelas palavras de empolgação e desafio no prefácio/explicação: "Mas - enquanto ele me falava ao telefone - eu já sentia nascer em mim a inspiração" (LISPECTOR, 1974, p. 9).

Notemos que a expressão, via crucis, pode alcançar múltiplos significados. Via é caminho, é trajetória; crucis é cruz, refere-se ao sacrifício, ao sofrimento. A via crucis percorrida pela ficcionista para tratar do tema espinhoso (sexo) foi de invenção e reinvenção, de simulação e dissimulação, revestindo-o com características de sagrado, profano, sublime e banal, que passam pelas citações bíblicas da epígrafe, pelas referências contidas no prefácio/explicação e culminam, talvez, na paródia da natividade, exercitada no conto em estudo.

Via crucis é o terceiro conto desse livro e corresponde a uma das três histórias encomendadas por seu editor, todas baseadas em notícias de jornais. O caso original foi a notícia de uma mineira que acreditava ter engravidado pelo Espírito Santo. No conto, Lispector usa de ironia e bom humor para narrar a história do nascimento de uma criança, parodiando a Natividade bíblica sobre o menino Jesus nascido da virgem 
Maria, e, ao mesmo tempo, problematizando o nascimento do próprio livro. A paródia, no entendimento dos séculos XX e XXI, é uma forma de criação/ recriação/ crítica, uma brincadeira bem-humorada, e, contraditoriamente, também séria. Uma forma de interrogar/ criticar precedentes históricos. Uma transgressão/duplicação textual autorizada (REGUERA, 2006).

Nas palavras de Gotlib (1995, p. 415-16), em a via crucis, Clarice Lispector, ao escrever esta obra, foi marcada pelo sentimento de inadequação, pela necessidade de vender seu texto, por sentir-se profanada pela obrigação de escrever sobre sexo. O livro é considerado pela biógrafa como um desvio na retórica clariceana, como uma experimentação literária. Nesse sentido, Reguera (2006, p. 37) ressalta que o dilema vivido por Clarice Lispector entre escrever por "encomenda", e escrever por "impulso", seguindo sua livre inspiração, aponta para a possibilidade de que a paródia exercitada na escrita do livro seja também entendida como uma forma de subverter e se revoltar contra as normas.

A morte da escritora criativa e o nascimento da escritora por encomenda seria a única via salvífica no caso? Segundo Clarice, "que podia fazer? Senão ser vítima de mim mesma" (LISPECTOR, 1974, p. 10). A autora encontrava-se tão obediente que não podia recusar o pedido de seu editor, nem mesmo deixar de atender aos apelos mercadológicos que, nas palavras de Gotlib (1995, p. 415) eram "sexo e mais sexo". "Só peço a Deus que ninguém me encomende mais nada. Porque, ao que parece, sou capaz de revoltadamente obedecer, como criança boba, eu a inliberta" (LISPECTOR, 1974, p.10).

Segundo explica Vieira (1987, p. 4), "a prosa de Clarice Lispector reflete aquela perspectiva, oriunda da tradição bíblica e judaica, que visa a comunicar, ao final de contas, uma mensagem espiritual”. De acordo com essa linha de raciocínio, é possível depreender que, na obra em estudo, o título, "Via crucis", dialoga com um referencial cristão e remete ao caminho do Cristo até sua crucificação no monte Calvário, carregando a 
sua cruz, assumindo assim sua missão salvífica de transformar a morte em vida.

Essa missão crística, relacionada à transformação, pode também representar o processo humano de autoconhecimento. Cristo é fonte de conexão, de religare (do latim, atar com firmeza) entre a morte do eu conhecido e normatizado, para o nascimento do outro, desconhecido, dentro de si (SERENTHA, 1986).

Assim, inicia-se o caminho da narradora e de suas personagens em busca do autoconhecimento, pois ao contrariarem seus instintos, seus impulsos, elas se distanciam de si mesmas, até que, através de sofrida via crucis, de algum modo conciliando-se com sua instintividade e impulsividade, desafiando as normatizações, atingem o seu religare e alcançam a experiência do renascimento, da ressurreição, tal como o Cristo.

\section{O menino-Deus}

O menino Jesus é Deus encarnado na crença cristã. O filho é a segunda pessoa da Santíssima Trindade, é Deus feito homem. Ele é considerado a ponte entre Deus e os homens por unir em si duas naturezas: a divina e a humana. É denominado Cristo por ter sido morto na cruz e ressuscitado ao terceiro dia, unindo a terra e o céu (SERENTHA, 1986)., pois sua cruz é o ímã que atrai para si todas as coisas (Jo 12,32). O caminho da cruz é entendido, na cristologia ao mesmo tempo, um caminho de dor e de amor. A dor do parto e o amor ao filho (SERENTHA, 1986).

A missão messiânica de salvação está intimamente relacionada à esperança. Ter esperança significa ver como possível a realização daquilo que se deseja; é ter confiança em coisa boa; a esperança é a segunda das três virtudes básicas do cristão (virtudes teologais ou virtudes da alma), ao lado da fé e da caridade. É encher-se de expectativa, de espera e de fé (SERENTHA, 1986).

Clarice Lispector, ao aceitar a encomenda, encheu-se de esperança 
e fé. Esperança de ver sua obra aceita, de receber o dinheiro de que tanto precisava e fé de que conseguiria escrever por encomenda. Maria das dores, protagonista do conto em análise, ao saber que estava grávida, também se sentiu repleta de esperança e fé. Ao aceitar, acolheu a sua cruz. Ao acolher a cruz, deixou algo de si nela e trouxe algo da cruz para sua própria vida. É a vida transformada, a vida nova comentada e pregada nas narrativas bíblicas.

Na figura da cruz está o Cristo: o começo e o fim da evolução criadora. Embora livre, a criação tem sua razão de ser: representar a manifestação da perfeição e do Amor divino. É na cruz que está toda a dignidade da transfiguração de sentido de dor para o amor, o caminho da autêntica felicidade, verdadeira vocação do Homem. A figura pública de Jesus representava o homem livre, aquele que não temia as castas dominantes e o poder; aquele que transgredia as tradições, o revolucionário (GOMES, 1989). Nesse sentido, Bonder (1998, p. 13) explica que "o ser humano é talvez a maior metáfora da própria evolução, cuja tarefa é transgredir algo estabelecido". Há dentro do animal moral homem uma dimensão capaz de transgredir possibilitando ao humano a ação co-criadora, ou seja, a evolução (BONDER, 1989).

$\mathrm{Na}$ obra em estudo, a presença da metáfora da natividade de modo paródico e transgressor do estabelecido pode ser interpretada como uma redenção. Para a ficcionista, a palavra a redimiu com o recurso da paródia para encenar o seu sacrifício; para a protagonista do conto, a gravidez fez morrer a vida profana e banal que levava ao lado do marido impotente e projetou-a na vida nova, na perspectiva de ser mãe de uma criança divina e colaboradora da criação. Como já mencionamos, Reguera (2006, p. 37) ressalta que o dilema vivido por Clarice Lispector entre escrever por "encomenda", e escrever por "impulso", permite que essa paródia clariceana seja também entendida como uma forma de subverter as tradições literárias. Seja na experiência transgressora da escrita sobre sexualidade com foco nas tormentas internas de suas personagens femininas, seja na necessidade destas encontrarem um cami- 
nho de se relacionarem bem com o próprio corpo e se realizarem como pessoas. O corpo é o próprio caminho.

Esse exercício de subversão do já estabelecido é uma via dolorosa. A dor é um sentimento resultante de um dano causado a outrem ou a si mesmo; pode ser causada por um pesar; ou ainda os sofrimentos provenientes do trabalho de parto; também pode ser entendida como referência aos sete padecimentos da Virgem Maria (BONDER, 1989), a saber: a profecia de Simeão a Maria, ao afirmar que uma espada transpassaria a alma da mãe divina (LC 2, 35). Em seguida, a fuga para o Egito, por ocasião da perseguição de Herodes (Mt, 2, 1-8); a perda do Menino Jesus no Templo (Lc 2, 41-51); a ida para o Calvário (Mt 27, 31 33; Mc 15, 20b-22; Lc 23,26; Jo 19,17); a Crucifixão de Nosso Senhor (Mt 27,34-38; Mc 15, 23-28; Lc 23, 33-34; Jo 19,18-34); a descida da Cruz e o sepultamento (Mt 27, 57-61; Mc 15, 42-47; Lc 23, 50-56; Jo 19, 38-42). Na tradição católica, essa lembrança é celebrada sob a denominação de Nossa Senhora das Dores (GOMES, 1989). A protagonista do conto chama-se Maria das Dores.

Com base na análise da obra em estudo, observou-se que a espada e a perseguição foram representadas pela crítica negativa que a obra recebeu; a perda do menino Jesus no templo, símbolo do sagrado, é a necessidade de profanar $\mathrm{o}$ ato criativo, vendendo-o como mercadoria no templo da arte; a ida para o calvário é a autora assumir o risco de ser condenada pela crítica.

Conforme os relatos do Gênesis, a desobediência é considerada uma transgressão moral (QUELL; BERTRAM; STÄHLIN; GRUNDMANN, 1987 , p. 1149-50). Por outro lado, Bonder (1998) defende que a alma tem em si uma necessidade de evolução que a força a romper com os padrões estabelecidos, isto é, a alma possui uma natureza imoral e transgressora. É a explícita possibilidade de escolha: obedecer ou desobedecer a moral vigente. A evolução torna-se possível quando há uma ação manifesta pronta para ser contestada, transgredida, desobedecida. 
"somos o produto de uma tensão" (BONDER, 1998, p. 21).

Como já mencionamos, a autora encontrava-se tão fraca (precisava do dinheiro) que não podia recusar o pedido de seu editor, nem mesmo não atender aos apelos mercadológicos. Também se sentiu tentada a experimentar o "fruto proibido" (grifo nosso) e transgredir. Assim como na narrativa bíblica, a ficcionista transgrediu, desobedeceu. Obedeceu aos dois desejos da alma criadora e criativa: "Entregou-se ao prazer de ser e ao de estar sendo" (BONDER, 1998, p. 21). Observa-se que é necessário não ser nem mais nem menos, apenas o suficiente. Esse cuidado é exatamente o que potencializa o ser, conforme ensina Bonder (2007). Nesse sentido, a linguagem clariceana adotada na paródia foi simples, objetiva, direta. Sem rodeios ou floreios. Cirúrgica.

\section{Maria das Dores-Mãe}

No conto paródico de Lispector (1974), Maria das Dores, mulher casada e virgem, mantinha-se nessa condição devido à "impotência" e a "paciência" de seu marido. Clarice Lispector não havia ainda escrito objetivamente sobre sexo, ou produzido algo explicitamente erótico, era como uma virgem que não experimentara esse prazer. Embora seja possível observar que, desde a publicação de seu primeiro romance em 1943, houvesse um erotismo implícito nas ações de suas personagens (NUNES, 1989; REGUERA, 2006). Reguera (2006) destaca que em Via crucis, depois da Anunciação da gravidez, sobressai a narração de uma dimensão corpórea, carnal, material em oposição a algumas formas de compreensão da espiritualidade na tradição cristã.

Notemos que o ventre virgem é a representação do ventre vazio que pode ser fecundado. É a alma pronta para ser fecundada e participar da ação criadora. A criação desenvolve-se no ventre, ou melhor, no corpo. As leis da tradição e a obediência a elas representam o território do corpo, no entendimento de Bonder (1998). A alma representa a desobediência que respeita tanto o passado quanto o presente e o futuro, pois, 
muitas vezes, a opção mais adequada e próxima ao cumprimento da lei é a desobediência à própria lei. Em muitas situações, uma ação que parece errada é a mais acertada. "A unanimidade expressa uma acomodação à verdade absoluta que é insuportável à vida e que tem grande potencial destrutivo. É a alma que detecta isso, são seus interesses que ficam prejudicados nessa unanimidade" (BONDER, 1998, p. 25).

A unanimidade, na obra, é caracterizada pela mesmice. A rotina do casal era monótona e parecia que jamais mudaria, sem uma vida conjugal na sua função primordial: procriar. Ressalta-se a passagem do Gênesis $(1,28 ; 9,1)$ na qual Deus ordenou aos homens que fossem férteis e que se multiplicassem. Inesperadamente, ela, virgem, engravida. O marido, ao saber da notícia, assume o papel de São José. O casal aceita sua missão e ruma para a fazenda de uma tia, para que a criança nasça em um estábulo, como o filho de Deus. Maria das Dores quer evitar que seu filho siga a via crucis, por isso, chama-o de Emmanuel, Deus conosco. O caminho do conhecimento ou do autoconhecimento é doloroso: "o caminho se arranha em nós, suas paredes atritam contra nossa pele e nos inflige feridas" (BONDER, 2007, p. 39). Isso ocorre quando não pedimos ajuda e ao denominar a criança de Deus conosco, a protagonista invoca a presença do divino para auxiliar na trajetória do menino. O sagrado conduz a pessoa de volta ao real, redime do engano sedutor da fantasia. O conto termina logo após o nascimento do menino, com o seguinte comentário do narrador: "Não se sabe se essa criança teve que passar pela via crucis. Todos passam" (LISPECTOR, 1974, p. 44).

Há uma constante intersecção entre realismo e ficção na obra em estudo. O conto começa com um susto que representa uma realidade bem feminina: a menstruação não veio. A mulher, então, procura a ginecologista que, como o anjo Gabriel, anuncia a boa nova: ela estava grávida de três meses. "Maria das Dores se assustou. Mas se assustou de fato" (LISPECTOR, 1974, p. 39). A ausência da menstruação é realidade muito feminina, e sempre provoca um susto. A maternidade é um papel biológico e social que cabe à mulher e, na cultura patriarcal, a função do 
controle de natalidade e o cuidado com os filhos são atribuições femininas, solitárias (GIDDENS, 1993).

Destaca-se que, em épocas remotas, a mulher quando sangrava era considerada impura e permanecia afastada do grupo até que o período menstrual cessasse (DE FRAINE, 1987, p. 1388). A impureza, então, é atribuída a uma contradição, pois o sangue é símbolo de vida e de fertilidade (BEHM, 1987, p. 1385). Na cultura judaica, a maternidade representa a fecundidade, a continuidade e a preservação do povo. A mãe representa também a coletividade. Em sociedades poligâmicas da antiguidade, os filhos eram distinguidos pelo nome da respectiva mãe (MICHAELIS, 1987, p. 921).

O amor maternal é representação do amor de Deus por sua criação (MICHAELIS, 1987, p. 9). O corpo materno é receptáculo de vida, tal qual a terra e a água. São correlatos de vida e morte, do sagrado e do profano. Dar à luz a um filho, ou a uma obra, seja ela de ficção ou não, é colaborar com a ação criadora do universo. É preciso consentir internamente para criar. É o "sim" de Maria ao aceitar conceber um filho. É o "sim" de Clarice ao seu editor. A paixão de Cristo, sugerida no título, sua morte na cruz remete a uma necessidade, não a uma opção. Jesus triunfou sobre a morte. A escritora sobreviveu às críticas. Encontrou um caminho para sua missão. O filho de Maria das Dores recebeu o nome de Emanuel - Deus conosco. Deus pai criador. Todo escritor é um criador.

Na narrativa bíblica, ao desobedecerem à ordem de não comer o fruto da árvore do conhecimento do bem e do mal, homem e mulher foram expulsos do paraíso: o homem recebeu o castigo de precisar trabalhar para seu sustento; a mulher passou a sofrer as dores do parto. A noção de pecado na narrativa bíblica do Antigo Testamento é relacionada a uma violação do sagrado, a uma transgressão da vontade Deus. Maria das Dores, até então infértil, desobedecia às ordens do criador de frutificar. O castigo é a morte. O afastamento simbólico da árvore da vida. A perda do paraíso. No conceito judaico, o corpo representado pela huma- 
nidade de Adão e Eva, desejava apenas procriar no território do Éden, no seu lugar de conforto a reprodução era a garantia de imortalidade (BONDER, 1998). A autora já estava consagrada, bastava-Ihe permanecer na repetição de seu estilo. Porém, o corpo não possui outro destino senão obedecer aos ditames da alma e seguir para outro território. Sair da situação de naturalidade e conformismo com as tradições e mudar, desobedecer, transgredir. Tal qual Clarice Lispector o fez. A imortalidade do corpo está vinculada à alma, e esta encontra-se comprometida com as alternativas que se apresentam fora do corpo, fora do lugar comum, longe do paraíso confortável e conhecido.

A árvore da vida é uma das representações simbólicas da cruz. É o caminho da realização e da felicidade, é fonte de prosperidade (ENGNELL, 1987, p.117). No sentido figurado cristão, a cruz representa desapego, sofrimento, sacrifício. Representa a prontidão para o martírio (SCHNEIDER, 1987, p. 338).

Dando continuidade à encenação e construindo a analogia, pode-se entender o nascimento do menino no conto como símbolo também do sacrifício da escrita desviante da ficcionista, tão criticada, e o desapego que precisou empenhar não se importando com seu nome e sua imagem de escritora consagrada. "Uma pessoa leu meus contos e disse que aquilo não era literatura, era lixo" e completou "Mas há hora para tudo. Há também para o lixo" (LISPECTOR, 1974, p. 10). Preservar tornou-se tão importante quanto transgredir no caminho de evolução do homem e de sua ação criadora. Há também a possibilidade de uma dissimulação do medo. "Sei lá se esse livro vai acrescentar alguma coisa à minha obra" (LISPECTOR, 1974, p. 65).

Em Via crucis, o medo do casal, protagonizado por Maria das Dores, era que seu filho, a quem queriam chamar Jesus, também precisasse carregar a cruz, como ocorreu com o Cristo. No simbolismo católico, levar a cruz significa o desprendimento e a entrega total da vida (SCHNEIDER, 1987, p. 33) ). "Minha obra que se dane. Não sei por que 
as pessoas dão tanta importância à Literatura. E quanto ao meu nome? Que se dane, tenho mais em que pensar" (LISPECTOR, 1974, p. 65). A cruz é o reconhecimento da mortalidade. É a expressão do pensamento daquele que não se autoglorifica e se reconhece dependente do mundo que o rodeia (SCHNEIDER, 1987, p. 338).

Fazendo o paralelismo com a paródia, "Mas parecia-lhe que se desse à criança o nome de Jesus, ele seria, quando homem, crucificado" (LISPECTOR, 1974, p. 42). A Virgem Maria aceitou sua missão ao ser interrogada pelo Anjo Gabriel. Disse sim à vontade divina. Clarice disse sim à vontade do editor.

E ela foi crucificada. Tão logo publicado o livro, Emanuel de Moraes (1974) afirmou no Jornal do Brasil: "é um dos livros que não deveriam ter sido escritos" e acrescentou "é lixo literário". Hélio Pólvora (1974), também no Jornal do Brasil, o descreveu como "a arte de mexer no lixo". Olga de Sá (1979) o considerou um desvio no conjunto da obra de Clarice. A crítica não ousou transgredir os caminhos do já estabelecido para um novo olhar, para o surgimento de uma nova forma de vida, para a transmutação da cruz-dor em cruz-amor: ressurreta, redimida. A crítica preferiu comparar o livro com os escritos anteriores e focar no aspecto de ter sido uma encomenda editorial. A ficcionista foi tratada como a pecadora bíblica, na passagem sobre a mulher adultera em Jo 8, 1-11.

\section{Tempo e espaço}

A notícia da gestação improvável e inesperada transformou a vida do casal e a chegada do menino tornou-se o centro do tempo e do espaço. "Era difícil esperar. O tempo não passava" (LISPECTOR, 1974, p. 43). Maria das Dores assumiu o papel de Virgem Maria "Um filho divino. Ela fora escolhida por Deus para dar ao mundo o novo Messias" (LISPECTOR, 1974, p. 40). Seu Marido transformou-se, ao longo do período gestacional, em São José: "deixara a barba crescer e os longos cabelos grisalhos chegavam-Ihe aos ombros. [...] arranjara para si um 
cajado. [...] sua túnica era de estopa. [...] com seu cajado ia meditar na montanha" (LISPECTOR, 1974, p. 43).

A criança divina, nascida sem a intervenção de um homem, conforme é citada no mistério Cristão e compartilhada com os mitos da antiguidade, simboliza a terra orientada para o céu, tornando-se uma terra transfigurada, uma terra de luz. Modelo de ponte entre o celeste e o terrestre (CHEVALIER; GHEERBRANT, 2009). O telefonema do editor transformou a vida da ficcionista. A "boa nova" era a encomenda; o sofrimento, o tema.

A sacralidade do tempo é marcada, muitas vezes, pela intersecção de passado e presente. O presente remete à eternidade, à fecundidade, é a vitalidade. Estes são atributos do sagrado. O passado transita em direção à morte. É aquele que finda, que não volta, que espirou, que perdeu sua força vital. Estes são atributos do profano. Três são as dimensões do tempo. A primeira parte do conto é marcada pelos verbos no pretérito perfeito, fazendo a indicação da conclusão dos fatos. Começa com o susto de Maria das Dores e termina com a constatação de que "ela fora escolhida por Deus para dar ao mundo o novo Messias" (LISPECTOR, 1974, p. 39-40).

A segunda parte, como a indicar a evolução da gestação do menino, foi toda redigida com os verbos no pretérito imperfeito. Nesse seguimento, são narrados os fatos que demonstram a espera, o caminho percorrido pelas personagens na sua transformação pessoal enquanto a barriga crescia. Termina quando chega a hora do parto. A terceira parte, se assim é possível considerar, tem os verbos no pretérito perfeito como um modo de narrar a consumação do nascimento da criança. Tem início "às três horas da madrugada" (LISPECTOR, 1974, p. 43).

Há nessa sequência uma alternância entre o pretérito perfeito e o imperfeito, misturando os aspectos de permanência, continuidade e de finitude. $O$ tempo presente caracteriza as falas das personagens em discurso direto, conforme exemplificado no trecho a seguir: "- Maria das 
Dores, mas que destino privilegiado você tem! — privilegiado, sim, suspirou Maria das dores, mas que posso fazer para que meu filho não siga a via crucis? - Reze, aconselhou a amiga, reze muito" (LISPECTOR, 1974, p. 41) E o ponto final: "Todos passam." (LISPECTOR, 1974, p. 44). Para intensificar a dúvida de Maria das Dores em relação ao destino do filho, o futuro do menino foi marcado com o futuro do pretérito: "O que lhe preocupava é que a criança não nasceria em vinte e cinco de dezembro" (LISPECTOR, 1974, p. 41).

O tempo de espera pode representar o tempo de uma trajetória, de uma vida, o tempo da criação. O tempo transforma, transmuta. Chegada a hora da criança nascer, eles foram para o estábulo. Até vaquinhas havia. Uma estrela grossa faiscava no céu no momento do nascimento do menino. Maria e José, na narrativa bíblica, precisaram peregrinar até Belém para responderem ao recenseamento imposto pelo edito de César Augusto, imperador romano à época. Chegados a Belém, Maria entrou em trabalho de parto e, como eram pobres e a cidade estava repleta de peregrinos, não conseguiram vaga em nenhuma estalagem. Maria deu à luz em um estábulo. A ida do casal ficcional para a fazenda de uma tia faz alusão a essa passagem bíblica. O menino nascido entre os animais, desprovido de luxo ou qualquer símbolo de riqueza, totalmente entregue e aberto ao seu destino. A preocupação maior da mãe era evitar-Ihe a via crucis.

A estrela é símbolo do espírito, em especial, do conflito entre as forças espirituais e materiais. Elas ultrapassam a obscuridade e podem representar o homem regenerado, radioso como luz (CHEVALIER; GHEERBRANT, 2009). A luz é sinal de redenção, alcançada pelo sacrifício de carregar a cruz-dor, no caminho estreito e escuro, superar o peso e a prisão das tradições ultrapassadas e finalizar a trajetória transgressora do encontro com a alma e com o novo. Repete-se: o caminho é o corpo.

Além da explícita referência do título à via sacra católica, nesse con- 
to é observável a presença de elementos cuja simbologia pode ser relacionada a aspectos considerados sagrados, tais como: o uso da cor vermelha (o sangue derramado), azul (manto de Nossa Senhora) e branca (a paz), os números cabalísticos, três (símbolo universal da totalidade e da triunidade do ser) e sete (totalidade do universo em movimento, plenitude dos tempos), a repetição de palavras e as incansáveis perguntas relacionadas à noite da natividade: "Mas que posso fazer para que meu filho não siga a via crucis? (...) Mas onde encontrar um estábulo?" E mais adiante: "Quem seriam os três reis magos? Quem Ihe traria incenso e mirra?” (LISPECTOR, 1974, p. 40-41).

A cor vermelha é símbolo universal do princípio de vida. Força vital, o poder do sangue e do fogo. Para muitas culturas, evoca o calor, a intensidade, a ação e a paixão (CHEVALIER; GHEERBRANT, 2009). "O frio deixava-Ihe as mãos vermelhas" (LISPECTOR, 1974, p. 43). No sangue está a vida de toda a carne, está o dom sagrado da vida (BORN et al., 1987). O sangue do Cristo foi derramado na cruz. Já o azul, é a mais profunda e imaterial das cores e conjunto de suas representações simbólicas está relacionado a esses dois atributos. É o caminho do infinito onde o real se transforma em imaginário, pois desmaterializa tudo aquilo que dele se impregna (CHEVALIER; GHEERBRANT, 2009). Ao sair da médica, Maria das Dores "comprou um casaquinho para o bebê. Azul..." (LISPECTOR, 1974, p. 40) e também o berço era azul. A tia "preparava o quarto com cortinas azuis" (LISPECTOR, 1974, p. 42).

O branco é a cor daquele que vai mudar sua condição. Pode representar tanto o início quanto o fim de um ciclo. Representa a ausência de cor ou a soma de todas as cores. É um valor-limite, cor de passagem, usada nos ritos de passagem: morte e renascimento. Cor da alvorada, da abóbada celeste, anterior a todo começo (CHEVALIER; GHEERBRANT, 2009). "Maria das Dores tomava grosso leite branco, com o terço na mão" (LISPECTOR, 1974, p. 43).

É interessante notar a utilização das vozes dos animais que 
compõem a cena do presépio para indicar a reação de Maria das Dores ao falar "ai Jesus" a cada nova contração. "Ai Jesus, pareciam mugir as vacas" (LISPECTOR, 1974, p. 44). E mais adiante "As vacas, acordadas, ficaram inquietas, começaram a mugir" (LISPECTOR, 1974, p. 43). Essa relação parece lembrar o aspecto animal do próprio homem, a natureza fundamental, a matéria corpórea de que os seres são feitos. Todos são criaturas e não criadores. A figura da vaca é símbolo do sagrado para muitas culturas. Na tradição judaica, simboliza a nutrição, a Terra nutriz, abundante (CHEVALIER; GHEERBRANT, 2009).

As palavras empregadas para destacar o garoto, a gestação e a hora do parto traziam no seu significado algo relacionado ao sagrado, a uma ideia superior. "Filho divino" (LISPECTOR, 1974, p. 40). "Ela se sentia toda iluminada [...] la à Igreja todos os dias" (p.41). A hora da iluminação" (p.43). Tal qual o rebento da Virgem Maria da narrativa bíblica, saudado pela prima Isabel com as seguintes palavras: "Bendita és tu entre as mulheres e Bendito é o fruto de teu ventre" (Lc 1,42). A hora da iluminação, do nascimento, pode ser uma referência não apenas ao ato criativo, mas também à conclusão, ao término.

A oposição entre morte e vida, entre vigor e fraqueza, pode ser representada pela condição de debilidade imposta pela impotência sexual do marido, São José, que, no conto, foi transformada em vida. Passou a trabalhar como carpinteiro, demonstrando tanto vigor criativo como a autora que produziu um livro em três dias. "e lá fazia seus trabalhos de marcenaria” (LISPECTOR, 1974, p. 42). O personagem trabalhava a madeira, a autora trabalhava as palavras. As referências às forças vitais são recorrentes: "o feto era dinâmico: dava-lhe violentos pontapés. Às vezes ela chamava São José para pôr a mão na sua barriga e sentir o filho vivendo com força. (...) Tratava-se de um Jesus vigoroso" (LISPECTOR, 1974 , p. 40; 41). A metáfora do vigor pelo trabalho parece relacionar-se também ao trabalho de parto, ao caminho estreito, ao sofrimento que antecede o nascimento: é preciso morrer para uma forma de vida, para poder nascer para outra vida. O nascimento é marcha, é caminhada para 
a luz, para um caminho mais amplo, um universo maior e iluminado.

O cenário do estábulo foi cuidadosamente preparado. "O estábulo estava ali, com seu cheiro bom de estrume e suas vacas" (LISPECTOR, 1974, p.42) e não bastava a constatação. Durante a espera, diariamente "de manhã bem cedo ia espiar as vacas no estábulo. As vacas mugiam. Maria das Dores sorria-Ihes. Todos humildes: vacas e mulher. Maria das Dores a ponto de chorar. Ajeitava as palhas no chão, preparando lugar onde deitar quando chegasse a hora" (LISPECTOR, 1974, p. 43). Também a ficcionista estava desprovida de vaidade, humilde, aceitando arriscar seu bom nome de escritora considerada "monstro sagrado" da literatura. "Aquele que se exaltar será humilhado, e aquele que se humiIhar será exaltado" (Mt 23,12).

Durante toda a narrativa as personagens comem. O ato de comer é representativo da ação concreta de alimentar o corpo. É a marcação do realismo na escrita da ficcionista. Ao sair do consultório médico, Maria das Dores, para refazer-se do susto que a notícia Ihe provocara, foi tomar café. Durante a gestação engordara muito e tivera desejos estranhos, como comer uvas geladas, atendidos por São José. Ela comia jabuticabas, brevidades... "A tia preparava lombinho de porco e todos comiam danadamente" (LISPECTOR, 1974, p. 43). Essa Tia, Mininha, morava em uma fazenda em Minas Gerais. Assim, para manter o paralelismo entre as duas narrativas, a de Maria e a de Maria das Dores, Lispector (1974) fez o casal mudar para a fazenda da Tia Mininha, em alusão tanto à passagem bíblica de Maria pela casa da prima Isabel, quanto a ida até Belém.

O tempo, devagar que ia, tinha sua morosidade agravada pela necessidade de representação da espera pela hora do nascimento, referida como "amanhecer" (LISPECTOR, 1974, p. 44). O termo amanhecer remete ao raiar de um novo dia, um novo tempo, uma vida renovada. Viver é permanência e luz, morte é tornar-se sombra. 


\section{Considerações finais}

O tom irônico usado na paródia em análise parece revelar uma postura transgressora adotada pela autora. Sua atitude transgressora desestabiliza os padrões literários da época, desobedece às tradições. Essa reação pode ser interpretada como uma ação reativa às exigências do mercado, uma vez que este foi um dos três contos escritos por encomenda, conforme a própria ficcionista esclarece no início da obra. A ironia empregada não parece ter a intenção de escárnio em relação à via sacra, ou à narrativa bíblica da natividade, mas sim, de uma releitura do evento judaico-cristão com ênfase na questão existencial ligada ao sofrimento, à maternidade e às experiências dolorosas.

$\mathrm{Na}$ verdade, o dizer nesta obra parece estar oculto, encenado, mascarado no jogo paródico da narrativa bíblica da natividade e na preocupação com o caminho doloroso a ser seguido. O corpo e os sentidos podem ser, geralmente o são, a via estreita e dolorosa que nos conduz ao conhecimento de nossa alma, nosso ser luminoso, livre e vivo. Muitas vezes, conhecer-se é um ato transgressor, um ato de desobediência. É romper com o estabelecido e aparente.

Somos, em alguma medida, o conjunto das marcas que as paredes estreitas do caminho deixam em nós; do que deixamos de nós pelo caminho e do que aprendemos durante o caminho.

Esta caminhada, esta via crucis, pode ser também entendida como uma representação do momento vivenciado pela ficcionista durante o conflito interior entre sua força vital criadora e sua condição sombria de precisar vender sua arte, considerada pela autora como uma forma de prostituição. Entre posicionar-se diante dos filhos e de si mesma escrevendo sobre um tema polêmico como o sexo, precisando fazer um livro erótico e a sua própria censura.

É possível, ainda, compreender essa caminhada como a expressão do conflito entre a pureza, ou pudor moral, ou obedecer, e a força vital criadora que impulsiona para a desobediência, para a transgressão. 
Toda escolha é uma via dolorosa. Abdicar de algo para obter outro supõe sofrimento, perdas e ganhos. Por este martírio, na vida, "todos passam". A ficcionista encontrou na paródia uma forma de encenar seu próprio sofrimento ao precisar aceitar a missão imposta pelo editor. Seu espírito criativo lapidou as palavras até que desse, dolorosamente, à luz, cada um dos contos do livro. O conto, Via crucis, se revela na nossa leitura como resultado produtivo de uma ação criadora.

\section{REFERÊNCIAS}

A Bíblia de Jerusalém. São Paulo: Edições Paulinas, 1985.

BEHM, J. SANGUE. In: BORN, A. Van Den et. al. Dicionário enciclopédico da Bíblia. 4a ed. Petrópolis: Vozes, 1987, p. 1385.

BONDER, Nilton. A alma imoral. Traição e tradição através dos tempos. Rio de Janeiro: Rocco, 1998.

BONDER, Nilton. O sagrado. Rio de Janeiro: Rocco, 2007.

BORN, A. Van Den et. al. Dicionário enciclopédico da Bíblia. 4a ed. Petrópolis: Vozes, 1987.

CHEVALIER, Jean; GHEERBRANT, Alain. Dicionário de símbolos: mitos, sonhos, costumes, gestos, formas, figuras, cores e números. Tradução Vera da Costa e Silva et al. 24. ed. Rio de Janeiro: José Olímpio, 2009.

DE FRAINE, J. SANGUE, fluxo de. In: BORN, A. Van Den et. al. Dicionário enciclopédico da Bíblia. 4ạ ed. Petrópolis: Vozes, 1987, p. 1388.

ENGNELL, I. ÁRVORE da vida. In: BORN, A. Van Den et. al. Dicionário enciclopédico da Bíblia. 4ạ ed. Petrópolis: Vozes, 1987, p. 117.

GIDDENS, A. A transformação da Intimidade. São Paulo: UNESP, 1993.

GOMES, Dom Cirilo Folch (O.S.B.). Riquezas da mensagem cristã. 2ed. rev. ampl. Rio de Janeiro: Lumen Christi, 1989.

GOTLIB, Nádia Battella. Clarice: uma vida que se conta. 2ª ed. São Paulo: Ática, 1995.

LISPECTOR, Clarice. A via crucis do corpo. Rio de Janeiro: Artenova, 1974.

MICHAELIS, W. MÃE. In: BORN, A. Van Den et. al. Dicionário enciclopédico da Bíblia. 4a ed. Petrópolis: Vozes, 1987, p. 921.

MORAES, E. de. A via-crucis de Clarice Lispector. Jornal do Brasil, 17 ago, 1974.

NUNES, Benedito. O drama da linguagem: uma leitura de Clarice Lispector. São 
Paulo: Ática, 1989.

PÓLVORA, Hélio. A arte de mexer no lixo. Jornal do Brasil, 13 ago, 1974.

QUELL, G; BERTRAM, G; STÄHLIN, G; GRUNDMANN, W. PECADO. In: BORN, A. Van Den et. al. Dicionário enciclopédico da Bíblia. 4ạ ed. Petrópolis: Vozes, 1987, p. 1149-50.

REGUERA, Nilze Maria de Azeredo. Clarice Lispector e a encenação da escritura em A via crucis do corpo. [livro eletrônico]. São Paulo: Editora UNESP, 2006.

SÁ, Olga. A escritura de Clarice Lispector. Petrópolis: vozes; Lorena: FATEA, 1979.

SARENTHÀ, Mário. Jesus Cristo ontem, hoje e sempre. São Paulo: Ed. Salesiana Dom Bosco, 1986.

SCHNEIDER, J. CRUZ. In: BORN, A. Van Den et. al. Dicionário enciclopédico da Bíblia. 4ạ ed. Petrópolis: Vozes, 1987, p. 338.

VIEIRA, Nelson H. A linguagem espiritual de Clarice Lispector. Travessia. Florianópolis, n.14, p. 81-95, 1ㅇs. sem. 1987. Disponível em: <https:periodicos.ufsc.br / index.php /travessia/article/view17509> Acesso 15 nov 2019. 